\title{
Weighed down by development: Reflections on early childhood care and education in East Africa
}

\section{Darcey M. Dachyshyn}

Abstract: This paper is based on qualitative research undertaken in West Nile Uganda and Coastal Kenya as part of a broader development project. A wide range of stakeholders, including government officials, parents, and early childhood practitioners were involved in sharing their perspectives of what life is like for young children (birth to age 8) in their homes, communities, and institutions. Data gathered were then brought back to community members to solicit action plans. The author brings to the data her reflections and lived experience as a mzungu (white person) brought to the region under the guise of development work and the ethical issues that ensued. It was clear that minority world discourses and conceptions of what constitutes a good life for children had permeated the value systems and goals of many adults in this majority world context. However, when challenged to think deeply about the systemic issues affecting their children, participants began to see the importance of finding ways to meld indigenous values, beliefs, and practices with the globalization agenda.

Key words: Uganda, majority world, indigeneity, globalization, early childhood. 
I came to be in Africa some thirty years after first considering living in this land so exoticized by the minority world, and while I am grateful for the opportunity I had to live and work in East Africa, what I offer upon reflection of that time is largely critical of the work I performed, and the way of life I benefitted from while there. My intent in offering these thoughts, based on research undertaken in Coastal Kenya and West Nile Uganda, along with my own lived experience, is to contribute to postdevelopment discourse (Escobar, 1992a) as it pertains to early years care and education.

\section{Project Expectations and Overview}

The initiative I was part of was sponsored by an international development agency, and supported in large part by Canadian donor and taxpayer dollars through the Department of Foreign Affairs, Trade and Development. The teaching and research I was involved in was meant to improve the education systems in Kenya, Tanzania, and Uganda through investment in teacher preparation. Reported on here is research undertaken in West Nile Uganda and Coastal Kenya in an attempt to understand the early childhood care and education landscapes in both these regions in order to better determine how the agency might more effectively intervene to increase the capacity of caregivers, teachers, school boards, agencies, centres, governments, etc. to deliver contextually relevant early childhood care and education services and programmes.

Along with building comprehensive understanding of the early childhood landscape, an equally important aim of the research process was to build communities of practice (Wenger, 1998) of key stakeholders who share a concern for early years care and education in their contexts and who are committed to understanding the local needs and aspirations families and communities hold for their children.

\section{Early Childhood Landscape}

Fieldwork for this project began in August 2013 when my first trip to West Nile Uganda was undertaken for teaching purposes. It was during this experience that first-hand knowledge of the context began to inform how the project might effectively and realistically be completed. During initial discussions with local stakeholders, it was suggested that to survey individuals through a traditional, paper question-and-answer methodology would lead to poor results. The context required a more face-to-face approach, yet to be able to obtain enough credible data to say the landscape was understood, 
the use of first hand interviews and focus groups requiring transcription and in some cases translation, were beyond the scope of the project. It was clear that a unique methodology was required.

Questions were devised that allowed participants to share the strengths and areas in need of change in five major categories related to the early years; a) home life, b) pre-school settings, c) the impact of health, nutrition, and safety on children's access to early years care and education, d) early primary grades $1-3$, and e) practitioner preparation. The questions used are provided in the Appendix.

The questions were posted individually on pieces of flip chart paper and either set on tables, or attached to the walls, depending on the venue. Participants, after providing consent to be involved, were invited to move about the room (or in one case, the tables gathered under the baobab tree) and, using felt marker pens, provide answers to as many or all of the questions they chose to. They were free to move about individually, with a partner, or find themselves having discussions with a small group gathered at a particular question. Participants supported each other if translation between local language and English was needed.

Research participants included government representatives, NGO members, parents, teachers, college tutors (instructors), certificate and master degree students, and alumni of the institution sponsoring the research. Seven focus groups were held in each region, with the numbers of participants in West Nile Uganda being 162, and 145 participants in Coastal Kenya. There were a near equal number of female and male participants between the two regions.

Responses to the research questions provided on the flip chart paper were word-processed and analyzed for common themes. Through this process it was determined that within the five aspects of early years care and education under consideration - home life; early childhood centres; health, nutrition, safety, and access to early care and learning; early primary experiences; and practitioner preparation, similar strengths and concerns were being expressed in both regions. As a result, what follows is a collective representation of the data organized according to common themes across both regions.

A second phase of the project involved taking the data back to the communities for action planning discussions. A reporting of this phase is beyond the scope of this paper, but the common areas identified for concrete ac- 
tion were: a) community sensitization, mobilization, and awareness building about the early years, b) creating income generating activities, c) enhancing child wellbeing, and d) advocating for government policy implementation.

The comments included here have been edited for English clarity while remaining true to the intended meaning and purpose of the statements. Following the participant responses, personal commentary is offered that transcends the data alone and encompasses overall impressions, learning, thoughts, and points of view of the principal investigator in relation to each area under consideration. Data related to home life and early childhood settings are provided in some detail, while in the other categories, access to early care and learning opportunities, primary grades 1-3, and practitioner preparation, data are discussed only limitedly in the interest of brevity.

\section{Summary of Home Life Data}

Participants in both regions offered many positive aspects about life for young children in their homes.

- Parents/guardians provide food, rest, clothing, good shelter, and chores in proper quantities (Koboko, Uganda)

- Home is a good context to learn about their cultural values and they are also taught the values that make a good citizen (NGO Team Member, Kenya)

In relation to the socialization of children, participants see the learning of gender roles as an important aspect of home life.

- Young children experience life in their homes by imitating their parents (Arua, Uganda)

Notions of communal caregiving were raised.

- In the regions there is a sense of community; children have regular contact with and access to extended family, relatives, and neighbours (NGO Team Member, Uganda)

Play was considered.

- Children share ideas with their peers as they play together and they im- 
prove their talents as they interact with others when they play together (Kilifi, Kenya)

Turning now to the aspects of children's home life that participants perceived as negative, or parenting practices that needed to be changed, issues of abuse, neglect, and child labour were cited often by participants. Drunkenness and the defilement of children were also raised as a concern.

- Children are left at home the whole day without an adult to show them the right ways or even just to attend to their needs (NGO Team Member, Uganda)

Both groups raised gender inequities as a problem within their communities.

- Children are not treated equally as boys are given preference in comparison to girls (Kilifi, Kenya)

In a similar vein, participants from both regions expressed concern that children were not being given enough opportunities for play.

- Children are not allowed to play with others or socialize; they are given chores and work to do at home, like taking care of their siblings, the home, and fetching water for cooking (Kilifi, Kenya)

Participants also expressed concern about the lack of direction being provided to some children.

- Most children are taken care of by house helpers who are not educated and the children spend most of their time watching TV rather than playing (Master Degree Graduate, Kenya)

Participants in both regions often stated lack of knowledge about education and its importance in the early years as a problem for young children in their homes.

- Some parents are illiterate and do not know the importance of education for young children, they send children to school at later ages, and cannot afford the school fees (Kilifi, Kenya)

The above statement introduces the reality of the low socioeconomic sta- 
tus of many parents in both regions. Here again, the child labour issue arises, this time in relation to poverty.

- A considerable number of children do not access school/learning but stay at home doing child labour because of poverty in the family (Kwale, Kenya)

\section{Commentary on Home Life}

In summary it is clear to see that for young children and their families in West Nile Uganda and Coastal Kenya, there can be many positive aspects to their home life, as well as some negative ones. Basic needs, moral development, gender socialization, and the communal aspect of life, where children experience care, love, discipline, and play all in good measure from a wide range of people are perceived as strengths within these communities. It is noteworthy that acquiring the skills and knowledge necessary for school readiness was not an oft-mentioned focus. Home life, when all is well, seems to be about having a good life physically, emotionally, socially, and morally.

When participants turned to outlining the negatives for young children and their families in the home context, child abuse, neglect, child labour, and lack of financial resources predominate. These are difficult and complex areas to wade into. It just so happened that when we arrived to conduct a data gathering session in one community, preschool age children were actively involved in bringing containers to one of the community water wells. This can be seen as an inappropriate and burdensome job for children so young, but in reality it was a joyful social learning event with close adult and older sibling involvement. As outsiders to this daily routine, we marvelled at the numeracy skills of ordering, classifying, numbering, etc. that were evident as each child knew exactly which containers to retrieved from the long line of containers set down beside the well. It is noted that of course children so small were aided in returning the full containers to their homes.

Observing this event occurred after a quintessential two hour drive past homestead after homestead where families were observed beginning their daily routines, involving chipping out a bit of dry land with their hoes while the day was still cool, herding goats, carrying wood and water, with all family members involved, children working alongside adults. It is acknowledged that what we observed, and what is being described here is a very idealistic and romantic notion of life within majority world settings, however, it is of- 
fered as an antidote to the minority world lens that too often interprets other ways of life as abusive and neglectful rather than different and in fact teaching children the exact funds of knowledge (Gonzalaz, Moll \& Amanti, 2005) they need in order to function in their context. Of course there is neither room nor cause for child abuse and neglect; every child deserves protection. However, determining the line between cultural ways of being and children's rights being affronted are lines that must be determined in context by community members and cultural brokers.

It is clear, the issues and negative aspects of home life for young children and their families focus a great deal on poverty. Children are not receiving their basic needs for food, shelter, clothing, health care, etc. because parents cannot afford to pay for these services. To expect school fees to be paid on top of providing for these basic needs is more than many families in these regions can afford.

It is typical, irrespective of context, to have the discourse of deficit thinking predominate until challenged. In almost all instances, participants started out placing blame on parents and insisting that all would be right with the world if parents would just treat their children better and pay their school fees. In fact, this was the oft-repeated refrain when I attended the Ugandan Independence Day celebration: "Keep your children in school! Pay your school fees and we can reach middle income status!" However, once engaged in critical dialogue about the systemic issues related to poverty and the sociocultural-historical context in which this situation has arisen, participants then began to see the bigger picture. It is imperative therefore that community of practice dialogue that problematizes, deconstructs, and reconceptualizes notions of poverty and ways of life be continued.

This section also calls for some commentary on gender issues. It has been my experience that the term girl child is often used in East African education contexts when addressing gender issues. The girl child is called upon to stay in school and to resist having children early. True, communities and families are asked to support the girl child in these endeavours, but ultimately, the girl child herself is being told to change, to be different, to go against the norm. This is a heavy burden to place upon girls and young women when what they see around them is the exact opposite of what they are being asked to do. In my trips up and down the road between the various locations where data were gathered, seeing young girls and women walking or riding on the back of motorcycles or bicycles with babies slung on their backs is the norm. To ask a young girl, or teen to go against that norm is 
putting undue pressure on her to stand out and be different. I would like to suggest that the girl child will want something different for her life when the wider society changes and makes it possible for girls and women to want something different.

\section{Summary of Early Childhood Programmes Data}

Parents/guardians from both regions have high expectations for what will occur when their children attend early childhood programmes. However, they are hampered in being able to have their children attend.

- Parents are ready to send children to nursery but because of poverty they cannot (Arua, Uganda)

Research participants were looking to governments for intervention.

- Parents/guardians expect the government to offer an inclusive education programme that does not discriminate between the rich and to take full responsibility for early childhood programmes, especially employment of caregivers, provision of porridge, play materials, and infrastructure (Kwale, Kenya)

A great deal more was said about finances when participants were asked to offer what is negative, or not working about pre-school programmes in the regions.

- Washrooms are inadequate, conditions are unhygienic, space and materials are inadequate for playing, and some early childhood centres have no snacks and milk for the children (Master Degree Graduate, Kenya)

Regarding the kinds of experiences parents / guardians want for their children while attending early learning settings, they expect the following.

- Parents expect children to speak good English, be able to count numbers and read after nursery education (NGO Team Member, Uganda)

- A firm foundation in education for better development of the region in the future is expected for children attending early childhood centres (Arua, Uganda) 
Aside from academics, overall holistic care and learning are anticipated.

- Parents/guardians expect their children to be taught both world values and spiritual development, be able to express themselves, socialize with others, and acquire good morals and values (Kilifi, Kenya)

When asked to list the things that are positive for young children when they attend early childhood programmes, the focus on school readiness and academic learning is highlighted.

- Children learn to sing, draw, and write; they benefit through cognitive development that shapes their reasoning and mind development; and they learn to be responsible for things when they go to school, like keeping time, keeping their books, keeping uniforms clean (Koboko, Uganda)

Socialization and play were also emphasized.

- Children develop their social skills in group settings, which is a foundation for future leadership (Primary Teachers College, Uganda)

- Children learn to like school when they are still young since there is a lot of play in the early childhood centres (Koboko, Uganda)

When asked to comment on what is negative or needs improvement about early childhood programmes in the regions, on top of finances already discussed, these shortcomings were stressed.

- Some of the early childhood caregivers are too harsh (Mombasa, Kenya)

- Children are not given enough stimulating activities and materials to use when at early childhood centres (NGO Team Member, Uganda)

\section{Commentary on Early Care And Learning}

By way of commentary let it be said that though these data were gathered in East Africa, it could have come from most anywhere in the world. Parents are worried about the future success of their children and most see education as a secure way to a better life; as such, in their minds, the sooner acquiring school readiness knowledge begins, the better. The significance and importance of becoming competent in English is also a common theme worldwide. Parents want a better life for their children, and somehow they 
have become convinced that increased academics in English are what they should want for their children. It would seem that an English speaking education continues to colonize.

When participants were engaged in critical dialogue that invited them to consider their sociocultural-historical context and what it is that they value, believe, and want for their children and communities, they began to think deeply about what kind of early care and learning settings they want. The intermingling of a post-colonial education legacy, indigenous values, beliefs, and practices, and globalization are the reality in this context. How to work out the complexities of this is a huge project. Participants though were keen to wade in and begin the process. They were appreciative of being brought together to think deeply and requested such opportunities to continue.

The dialogue around who pays for early care and learning for preschool age children is a critical one. Again, the worldwide discourse is that children need to be in learning settings outside their homes in order to meet the UNESCO Sustainable Development Goals - but who pays? One of the reasons for high education levels in the minority world is because governments have prioritized the spending of tax dollars on education, but even then preschool care and education is more often than not the burden of the family. For families in majority world settings, as with those of low socioeconomic status in the minority world, paying for early care and learning becomes de-prioritized in the face of meeting basic needs. Deep questions of what parents and communities want for their children and how to achieve these goals must include a wide range of stakeholders and be conducted in such a way as to reach beyond rhetoric and invite contextually relevant ways of proceeding.

\section{Summary and Commentary on Health, Nutrition, Safety, and Access Data}

This statement made by a participant from Mombasa provides an apt summary of the issues related to health, nutrition, safety, and access to early care and learning.

- Health, nutrition, safety and access to healthcare improve the life expectancy of the children and help them get strong physically, mentally, and socially. However, in the coastal region, because of poor or no access at all due to poverty, the children find it difficult to manage a full life. Therefore they suffer malnutrition, poor growth and unstable academic performance in class. They do not consistently attend school (Mombasa, Kenya) 
Poverty and low socioeconomic status are reoccurring themes with significant impact on early care and learning. Cultural beliefs and values were also mentioned as impacting on access to early care and learning.

- In the region there is the cultural belief that knowledge of religion is more important than formal education (Mombasa, Kenya)

Socioeconomic status and culture/contextual beliefs seem to be at the centre of issues related to children being able to access early care and learning. In the time I have spent in East Africa, because I have been in education settings, I have been amongst the privileged healthy members of the population. It would seem that those who have access to health care, either by virtue of socioeconomic status or access to donor driven health care, are the ones able to consistently be involved in education settings. This would apply both to children and adult practitioners. What participants shared reinforces the interrelatedness of socioeconomic status, health, nutrition, safety, and opportunities for access to learning. It is incumbent therefore that further interventions be undertaken in an integrated fashion, with a wide range of stakeholders from at the least, the health, education, and government sectors involved, so that the complex web of factors behind access are addressed in a holistic manner.

\section{Summary and Commentary on Primary Grades 1-3 data}

Parent/guardian expectations for the early primary grades of school fall into two categories, academic and non-academic.

- Parents expect their children to acquire the basic required knowledge and skills to help them to pursue their learning smoothly, and are fluent in both Kiswahili and English (Kwale, Kenya)

- Parents/guardians expect an all-rounded education system, and for their children to have good manners, be disciplined in whatever they do, either at school or even at home, and learn the moral values of the society (Mombasa, Kenya)

Unfortunately though, there are many negative aspects to early schooling, and changes parents/guardians would like to see made.

- Early schooling suffers because of a lack of instructional materials, hun- 
ger, lack of proper health care, long distances to travel, and inadequate payment of teachers (Primary Teachers College, Uganda)

Concern was also expressed about home-school relationships.

- Little support is given from parents, especially in rural communities for the provision of scholastic materials, school uniforms, nutrition, and moral support (Yumbe, Uganda)

Issues raised here clearly mirror those of the previous sections - finances, an emphasis on academic learning, and concerns for child wellbeing were continually raised. Similar to the matter of parents receiving the blame when wider systemic issues might really be at play, so too do teachers often get the blame for being less than adequate in a system that is completely unconscionable. Once again, when engaged in critical dialogue, participants began to see the working conditions of teachers and the learning contexts children are subjected to in public school settings as more to blame than individuals.

\section{Summary and Commentary on Practitioner Preparation Data}

The overall term practitioner preparation is used to take in the three cohorts of people who head classes or programmes related to the age group birth to age 8 . The term preparation, rather than the more common term training is used, as a means of highlighting the need for early childhood practitioners to be reflective and critical thinkers, not merely people who have been trained to do a job. Caregiver is used to refer to those who work with children and families before the start of formal schooling, teacher is reserved for those heading classes in primary grades $1-3$, and the term $t u$ tor refers to college level practitioners teaching pre-service and in-service teachers.

In both regions a lack of recognition and support for early childhood caregivers was commented on.

- Early childhood education is good but the caregivers are not recognized in terms of employment and remuneration, therefore they lack confidence in performing their duties. All educators should be employed under one umbrella so that they can have job security and also progress with their further studies (Kilifi, Kenya) 
Regarding teacher preparation, it was clear there exists an ideal image of what this preparation should entail.

- Teachers should learn how to develop children holistically, i.e. physically, mentally, socially, spiritually, emotionally, and morally (Kwale, Kenya)

According to participant comments, however, the preparation of teachers is much less than the ideal expressed above.

- Pre-service teachers are not prepared well due to lack of facilities such as buildings, teaching/learning materials (Mombasa, Kenya)

As well, some of the personal characteristics expected of graduated teachers are falling short of the mark.

- Most teachers do not put into practice what they have learned after completing their course, and work for the sake of earning a living not having children at heart (Certificate Course, Kenya)

In an ideal situation, participants believe it is the job of college tutors to help pre-service and in-service teachers become effective.

- Tutors help future teachers to understand the individual needs of children, build the special skills required in education, understand childhood growth and development, inform about appropriate methodology, and provide effective preparation of a variety of learning materials (Primary Teachers College, Uganda)

Unfortunately however, many factors stand in the way of tutors performing their duties.

- Long distances to travel, since some tutors are not accommodated at the colleges, makes it difficult for tutors to do their jobs (Koboko, Uganda)

My first encounter with either of the two focus regions for this project was in delivering a certificate course to college tutors in West Nile Uganda. I was taken aback by the competence, knowledge, and commitment I perceived from each of the participants in the face of the surroundings - the rudimentary facilities, the lack of resources and teaching materials, the large class sizes, etc. I wondered what these very capable tutors might be able to ac- 
complish if given the tools and circumstances more in keeping with teaching and learning.

As time went on I began to wonder what disservice we might be doing in bringing constructivist pedagogy to the regions, without the infrastructure necessary to back up the theory. Constructivism was born out of a context of small, highly resourced, middle-class learning settings. To think we can simply transplant that methodology to East African contexts is highly problematic. It is imperative that minority world notions of teaching and learning be introduced from a critical thinking perspective and be analysed for their relevance to majority world contexts.

The competence of individual practitioners is often cited as a problem, but I am convinced it is the systemic issues that surround practitioners that are the problem. If issues related to policy and infrastructure for example were addressed, I have no doubt this would lead to more competent caregivers, teachers, and college tutors.

As was earlier discussed in relation to parental issues, there is a discourse of individualism at work that places blame on people rather than systems. I do not believe that either parents or educators set out to do a less than adequate job, but rather it is systemic circumstances that get in the way of people being who they would like to be. While we need to continue to intervene in the lives of individuals, and that means continuing to work with practitioners to improve their capacity, it is just as imperative to be putting pressure on governments to take the steps necessary to provide policy and infrastructure that is conducive to teaching and learning.

I would be remiss to conclude my commentary on the data intended to help understand the early childhood landscape in Coastal Kenya and West Nile Uganda without addressing the issue of children with special needs. Participants often cited these children, calling for more focused attention and intervention. In theory, as an early childhood practitioner, I am firmly grounded in inclusion, and the needs of all children, irrespective of ability, being met within the same setting. Knowing however the challenges that presently exist in East Africa to meet the needs of any learner because of the lack of resources, I am at a loss to know how to proceed. 


\section{Renewed Possibilities}

It needs to be asked at this juncture - What is the point of all these words? What is there to say that has not already been said elsewhere? Some 50 years ago Frantz Fanon (1961) gave us a detailed accounting of the colonial psyche. The 1990's brought about a focus on the response of the first-world to the third-world and the incumbent culpability of the minority world in the perpetuation of majority world dependence (Chew \& Denemark, 1996; Escobar, 1992a, 1992b, 1995; Latouche, 1993; Munck \& O’Hearn, 1999; Rahnema $\&$ Bawtree, 1997). More recent works continue in this vein (Haslam, Schaefer \& Beaudet, 2012; Rist, 2014; Veltmeye, 2011). In a special issue dedicated to critiquing the impact of development work framed within Education for All initiatives, Bloch and Swadener (2009) and many others have clearly identified the hegemony of current early childhood interventions in the majority world in the name of development. What is there to offer then by way of renewed possibilities?

Elsewhere I have written about a way of being in the world with young children that I would like to extrapolate to encounters with majority world contexts (Dachyshyn, 2015).

I believe we do want to set a direction with the young children in our lives, but not through force, coercion, domination, or one right-way thinking. The direction I deem needs to be determined in relationships of reciprocity, generosity, kindness, and be deeply rooted in contextually relevant values, beliefs, and practices. (p. 39)

I also wish to cast back to our critical thinking roots in education, to the words of Paulo Freire. Love, faith, and hope, humility and humanism, along with trust, dialogue, and communication seem to be at the heart of Freire's message of conscientization.

Freire (1998) views hope, reinvention of the future, and critical optimism as central in making the world a better place. To take such an approach however requires throwing off the cloak of oppression and immobilist fatalism. This fatalism though, Freire suggests is "nourished by the oppressors" (Freire, 1998, p. 102).

Tired and anesthetized, in need of everything, they [the oppressed] are easy prey for aid-and-assistance policies that further immerse them in a mind-narrowing daily existence. (p. 45) 
This was by all means my experience in East Africa. It was very clear that as a white Canadian, I represented money and so was revered wherever I went. Furthermore, my life as an expatriate was palatial in comparison to that of local citizens. I felt terribly uncomfortable in this position of power and privilege. Freire writes, "No matter that the oppressor eat well, be well regarded, or sleep well. It would be impossible to dehumanize without being dehumanized" (Freire, 2014b, p. 89). Freire sees it necessary to free both the oppressed and oppressor of this cycle of dependence.

The term assistencializing (1998) is used to explain the relationship that exists between minority and majority world contexts. Freire clearly emphasizes that the way out of this current relationship is to look beyond the individual, to the systems that perpetuate this way of being.

One of the main differences between assistance policies and those that assist without "assistencializing" is that the former insist on the suggestion that the great big problem with the oppressed lies in deficiencies of nature; the latter, on the other hand, underscores the importance of the social, the economic, and the political: in sum, power. (p. 46)

Freire suggests the oppressed have internalized the image of the assistance dependent other that is perpetuated by the oppressor. To overcome this requires the oppressed to "eject this image and replace it with autonomy and responsibility" (Freire, 2009, p. 47). I can empathize that, for the average citizen, ridding oneself of the legacy of oppression that exists, and taking action in the face of overwhelmingly daunting poverty and corruption is a fearful prospect. I was continually frustrated though with government officials that seemed to have little regard for bettering the lives of their own people. On the other hand, why should governments care for their citizens, when multitudes like myself are there doing it for them!

Looking to systems rather than individuals is crucial.

We will have to realize that victory over destitution and hunger is a political struggle in support of profound transformation in the structures of society. For that reason, we need to approach problems in such a manner as to invite people to understand the relationship between the problem and other factors, like politics and oppression. (Freire, 2007, p. 7) 
Educators are central to this process.

"The political nature of education vehemently demands that teachers take a stand for themselves as political beings, that they discover themselves in the world as political beings, rather than as mere technicians or persons of knowledge" (Freire, 2007, p. 60). "Critical thinking and the quest for mutual humanization" (Freire, 2009, p. 75), along with problem-posing education that "involves a constant unveiling of reality" (p. 81), must be at the heart of all teaching.

It's not the philosophers of education who are going to change pedagogy, but the politicians who will do it in response to our pressure, always assuming that we exert pressure on them. Education is an eminently political activity. (Freire, 2014a, p. 34)

Whatever the language you wish to use, conscientization of the oppressed as is the case with Freire, or bringing about social movements, in the language of Escobar (1992a), or provoking grassroots postmodernism, as is the case with Prakash and Esteva (2008), addressing the inequities of our world is a collective responsibility. Freire asserts that the oppressed have a right to be angry, and that anger can be used as a motivation to fight oppression (Freire, 2004). This must be done though within relationships of dialogue and reciprocity, rather than power and coercion. "The pursuit of full humanity, however, cannot be carried out in isolation or individualism, but only in fellowship and solidarity (Freire, 2009, p. 85).

In East Africa, as I suspect in multiple other majority world contexts, as minority world outsiders, we ought to see our role not as one of saviour, which is all too common the view, but rather one of co-humans working together to make the world a better place. "It is not our role to speak to the people about our own view of the world, nor to attempt to impose that view on them, but rather to dialogue with the people about their view and ours" (Freire, 2009, p. 96). It has been my experience that people concerned with early years care and education in East Africa are hungry for deep dialogue and are not looking for quick fixes and transplanted ideas. I believe that if minority world academics and development professionals are to be a continued presence in majority world contexts that our role be one of engendering critically knowing communities of practice (Mac Naughton, 2005) that allow participants opportunities to problematize, deconstruct, and reconceptualize issues they identify as important. Assistencializing hegemonic early childhood discourse and one-size-fits-all conceptions of care and education have no place in the world Paulo Freire advocated for. 


\section{References}

Bloch, M., \& Swadener, B. (2009). "Education for all?" Social inclusions and exclusions - introduction and critical reflections. International Critical Childhood Policy Studies, 2(1). 1-14.

Chew, S. C., \& Denemark, R. A. (1996). The underdevelopment of development. Thousand Oaks, CA: Sage.

Dachyshyn, D. M. (2015). Being mindful, heartful, and ecological in early years care and education. Contemporary Issues in Early Childhood, 16(1), 32-41.

Escobar, A. (1992a). Imagining a post-development era? Critical thought, development and social movements. Social Text, 31/32, 20-56.

Escobar, A. (1992b). Reflections on 'development': Grassroots approaches and alternative politics in the third world. Futures, 24(5), 411-436.

Escobar, A. (1995). Encountering development: The making and unmaking of the third world. Princeton, NJ: Princeton University Press.

Fanon, F. (1961). The wretched of the earth. New York, NY: Grove Press.

Freire, P. (1998). Pedagogy of the heart. New York: Continuum.

Freire, P. (2004). Pedagogy of indignation. Boulder, CO: Paradigm Publishers.

Freire, P. (2007). Daring to dream" Toward a pedagogy of the unfinished. Boulder, CO: Paradigm.

Freire, P. (2009). Pedagogy of the oppressed. New York: NY: Continuum.

Freire, P. (2014a). Pedagogy of commitment. Bolder, Co: Paradigm Publishers.

Freire, P. (2014b) Pedagogy of hope: Reliving pedagogy of the oppressed. London, UK: Bloomsbury.

Gonzalaz, N., Moll, L. C., \& Amanti, C. (Eds.). (2005). Funds of knowledge: Theorizing practices in households, communities, and classrooms. New York, NY: Lawrence Erlbaum.

Haslam, P., Schaefer, J., \& Beaudet, P. (Eds.). (2012). Introduction to international development: Approaches, actors, and issues ( $2^{\text {nd }}$ ed.). Don Mills, ON, Canada: Oxford University Press.

Latouche, S. (1993). In the wake of the affluent society: An exploration of post-development. London, England: Zed Books.

Mac Naughton, G. (2005). Doing Foucault in early childhood studies: Applying poststructural ideas. London, UK: Routledge.

Munck, R., \& O’Hearn, D. (Eds.). (1999). Critical development theory: Contributions to a new paradigm. London, England: Zed Books.

Prakash, M. S., \& Esteva, G. (2008). Escaping education: Living as learning within grassroots cultures ( $2^{\text {nd }}$ ed.). New York, NY: Peter Lang.

Rahnema, M., \& Bawtree, V. (Eds.). (1997). The post-development reader. London, England: Zed Books.

Rist, G. (2014). The history of development: From western origins to global faith $\left(4^{\text {th }}\right.$ ed.). London, England: Zed Books.

Veltmeyer, H. (Ed.). (2011). The critical development studies handbook: Tools for change. London, England: Pluto Press.

Wenger, E. (1998). Communities of practice: Learning, meaning, and identity. Cambridge, England: Cambridge University Press. 


\section{Appendix}

\section{Focus Group Questions}

1. What is positive about the way young children experience life in their homes, and what are the common child rearing practices utilized in the community/area?

2. What is negative about the way young children experience life in their homes, and what childrearing practices need to be improved upon?

3. What is positive about the way young children experience nursery centres, and how do children benefit from attending nurseries/early childhood centres in the community/village or region?

4. What is negative about the way young children experience nursery centres, and what needs to be improved upon in the nurseries/early childhood centres in the community/village or region?

5. What expectations do guardians and parents have of nurseries/early childhood centres?

6. What is positive for young children in early primary grades in school?

7. What is negative for young children in early primary grades in school, and what should be improved or dropped in the way early grade children (P1-P3) learn or are supported?

8. What expectations do guardians and parents have for early primary grades in school, and what are their expectations of what children should be learning in the early grades?

9. What is positive about the way caregivers are prepared for working with young children?

10. What should be improved about the way caregivers are prepared for working with young children, or what do you think is lacking/missing in the way the caregivers are prepared for working with children?

11. What is positive about the way teachers are prepared for working with young children?

12. What is negative about the way teachers are prepared for working with young children, or what do you think the teachers should learn/know about working with young children that they are not taught?

13. What is positive about the way college tutors are prepared?

14. What is negative about the way college tutors are prepared, or what do you think college tutors should learn/know that they are not taught currently?

15. What affects children's attendance at nurseries/early childhood centres, and primary schools in the region? 
16. How do health, nutrition, safety, and access to health care affect young children in the region?

17. What agencies support the work of caregivers and teachers in the region?

18. What else would you like to tell us about the early childhood care and education landscape in the region?

\section{Author:}

Darcey M. Dachyshyn, Ph.D.

Seneca College of Applied Arts \& Technology

School of Early Childhood Education

Toronto

Canada

Email: darcey.dachyshyn@senecacollege.ca 